\title{
Development Of Implicit Leadership Theories Prior To Training Or Employment
}

Dean E. Frost, Bemidji State University, USA

\begin{abstract}
This empirical study explored the development of implicit leadership theories among 16 to 18 year-old students in secondary schools prior to any formal leadership training or full-time employment. Students from governance, athletics, clubs, performance groups, and part-time work groups completed interviews and questionnaires. Adult leaders of activity groups also completed questionnaires. Results were analyzed by activity and role (e.g., student leader, student group member, and adult supervisor) for three separate dependent variables: Adult Leaders, Leaders in General, and Student Leaders. Results show that adolescents categorize leader behavior into similar constructs that have been previously established by research with adult samples experienced in organizational life. Experience in groups but not necessarily as a leader contributes to developing implicit leadership theories and type of activity guides such leadership attributions. Gender differences in the expectations for leaders were found and support the existence of early socialization into gender-specific leadership role stereotypes.
\end{abstract}

Keywords: Implicit Leadership Theory; Leadership Development; Gender Role Stereotypes

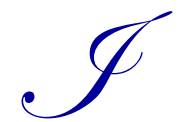

t has been argued that through their own social experiences in workgroups or through socialization, people develop implicit leadership theories or ILTs (Eden \& Leviathan, 1975; Engle \& Lord, 1997; Epitropaki \& Martin, 2004; Foti \& Luch, 1992; Kenney, Schwartz-Kenney, \& Blascovich (1996); Lord, Foti, \& DeVader, 1984; Lord \& Hall, 2005; Lord \& Mayer, 1993; Ritter \& Lord, 2007; Rush, Thomas, \& Lord, 1977; Shaw, 1990). In this explanation of leadership development individuals make assumptions concerning the behaviors, traits, and abilities needed for effective leadership in organizations. Individuals form mental representations or schemata for categorizing leaders (Nye \& Forsyth, 1991) and these leader prototypes or cognitive summaries of the most common features of leaders then create expectations for supervision during employment. Prototypes are amalgams of all the elements one thinks of when considering the notion of leader as a major factor of success in task performing groups. From these prototypes, individuals form expectations of leader behavior. In Calder's (1977) proposal for a new attributional paradigm for leadership he states 'to imply leadership, an observed behavior must be typical in the sense that the differentiated behavior falls within a set of behaviors associated with leadership expectations' (p. 190). An emphasis on the expectations for leaders and the perception of leadership is the hallmark of implicit theories and not on the evaluation of leadership effectiveness or behavioral performance of leadership functions. It is not the actual performance level of a leader's actions that typifies implicit leadership models but instead there is a focus on ideal leadership models (Ritter \& Lord, 2007).

The present study seeks empirical data on what leadership expectations are held by adolescents in the last two years of secondary school education. Specifically, this study hopes to determine the meaning of leadership to a particular group of students and student leaders in their various situational contexts. Here situational context refers to the type of extra-curricular activity in which the students and their adult supervisors are involved. 'A person's implicit leadership theory (ILT) is based on beliefs on how leaders generally behave and what is expected of them.... that suggest individuals are labeled as leaders or non-leaders based on cognitive categories' (Nichols \& Erakovich, 2013; pp. 182-183).

Current practices in leadership education places a great deal of emphasis on experience (Finderoff, 1991). Thus, the underlying belief is that to learn about leadership and what it means to be an effective leader, one must play the part of a leader. The demand for leadership education in the U.S. has come from the Secretary's Commission on Achieving Necessary Skills (SCANS; U. S. Department of Labor, 1991). The purpose of the first SCANS report, What Work Requires of Schools, was to identify the necessary skills for high school students to successfully make 
the transition from school to work. The commission specified 'exercises leadership' as one of the 20 workplace competencies to be integrated into mainstream curricula. The report also listed competencies often associated with leadership including such actions as managing human resources or materials, managing facilities, interpreting and then conveying information, and negotiating with others. Further, the value placed on leadership education and experiences is reflected by the fact that these are listed as criteria within numerous college admissions and scholarship applications.

The assumption of such programs is that students and adults have similar needs for leadership and similar interpretations of what it means to be a leader (i.e., mental models for leadership effectiveness). While existing programs may be worthwhile exercises, they have failed to define important aspects of the nature of leadership (c.f., Pfeffer, 1977) for young people. They tend to reflect untested assumptions about how adolescents experience groups and leadership. They may also do little to serve the needs of students leaving school settings and moving directly into the workforce. Perhaps most importantly, they reflect many untested assumptions about the way school experiences help to form leadership perceptions in late adolescence and young adulthood. As the number of school leadership education programs has increased there still remains a dearth of research in the field. As may be concluded by reviewing Bass (2008), most research examining student leadership is centered on university students. As a result, the pre-university school leadership curricula in existence have very little basis in leadership research.

The conceptual basis for the present research is derived from the hierarchy of implicit leadership theories that organizes much of the research on ILTs (Den Hartog, House, Hanges, Ruiz-Quintanilla, Dorfman, 1999; Lord, Foti, \& De Vader, 1984; Lord, Foti, \& Phillips, 1982). The first level of this hierarchy, which is labeled superordinate, contains attributes describing leadership in general. The second level, which is labeled basic, refines the ILT by including situational or context cues such the type of group or organization in its description of desired leadership. The subordinate level is the third in the hierarchy and refines the ILT further by including specific role information or interpersonal characteristics.

In prior research relevant to the development of superordinate ILTs, Ayman-Nolley and Ayman (2005) as well as Atonakis \& Dalgas (2009) have shown that young children (e.g., pre-school age) can draw an image of what a leader is or state what amounts to an implicit leadership theory for political leaders. Establishment of superordinate ILTs is fundamental to organizations and leadership thus contributing to the overall perception of a group or organization (Lord, De Vader, Alliger, 1986). The first research proposition of this study is that secondary school students will demonstrate use of leadership expectations consistent with adult ILTs using behavioral expectations for task performing group leadership (see Table 1).

The idea that social-identity is influenced by group membership is not new (Hogg \& van Knippenberg, 2003) and the concept of a basic level for ILTs may reflect group effects. What is seen as ideal or effective behaviors for a specific group's leadership may reflect a type of group prototype which defines what type of leader is valued by the group. The group's tasks and goals contribute to the members' ILTs. Baumgardner, Lord, and Foti (1990) found that experts and novices both mention experience in a work context in their ILTs. The second research proposition of this study is that secondary school students will show significant differences in the behavioral expectations for leaders across types of group activities (See Table 1).

Early in the literature on ILTs Eden and Leviathan (1975) argued that raters' ILTs were a significant determinant of the factor structure of supervisory behavior rating scales. Most social psychological studies of the development of person concepts look at perceptions formed on limited familiarity (Park, 1986). Foti and Luch (1992) note the same is true for research on ILTs. It is the third research proposition of this study that secondary school students will show significant differences in expectations for leaders depending on the role of the target leader relative to the student doing the rating (see Table 1).

Individual characteristics like personality traits (Lord, De Vader, Alliger, 1986) and intrinsic motivation (Epitropaki \& Martin, 2005) have been used to study ILTs but gender differences have not been extensively studied. As the percentage of women in leadership positions rises in the workforce, it becomes increasingly more relevant to examine differences between male and female leaders. Research has supplied evidence that both supports and refutes differences between men and women leaders (Ayman \& Korabik, 2010; Bass, 2008; Eagly \& Chin, 2010); Eagly \& Johnson, 1990; Eagly \& Steffen, 1984; Eagly \& Steffen, 1986). 
Existing studies of implicit leadership show some evidence of their consistent use across male and female perceivers. However, Epitropaki \& Martin (2004) found that females rate their ideal leader as more understanding, sincere, and honest than do male raters. Stephenson (1998) found that males rated such traits as aggressive and competitive as more desirable than did females. Betts, Morgan, \& Castiglia (2008) have found evidence that male university students compared to female university students when identifying public figures as leaders used more behavioral expectations than females did who in turn used more trait attributions than males did.

No research could be found that has explored differences between male and female expectations for leaders at the secondary school level. An additional aim of these studies is to examine sex differences in the use of ILTs. It is important to stress that the current research is concerned with mental models of leader behavior and not with predicting actual leadership behaviors practiced or their frequency of practice. It is the fourth research proposition of this study that significant evidence of gender differences in ILTs will be most apparent at the superordinate level of ILT for leadership in general (see Table 1).

Table 1. Hypothesized Effects on Implicit Leadership Theories By Four Perceptual Variables

\begin{tabular}{|c|c|c|c|c|}
\hline $\begin{array}{c}\text { Hierarchical Level of Implicit } \\
\text { Leadership Theory }\end{array}$ & $\begin{array}{l}\text { Leader as the } \\
\text { Target of the } \\
\text { Perception } \\
\end{array}$ & $\begin{array}{l}\text { Role of the } \\
\text { Leader Relative } \\
\text { to the Perceiver }\end{array}$ & $\begin{array}{l}\text { Group Activity } \\
\text { or Nature of } \\
\text { Group Perceived }\end{array}$ & $\begin{array}{c}\text { Gender } \\
\text { Difference } \\
\text { Perceived } \\
\end{array}$ \\
\hline & \multicolumn{4}{|c|}{ Most Apparent Effect } \\
\hline $\begin{array}{l}\text { Superordinate: } \\
\text { 'Leaders in General' }\end{array}$ & $\begin{array}{c}\text { Research } \\
\text { Proposition } 1\end{array}$ & & & $\begin{array}{c}\text { Research } \\
\text { Proposition } 4\end{array}$ \\
\hline $\begin{array}{l}\text { Basic: } \\
\text { 'Leaders in a Specific Group' }\end{array}$ & & & $\begin{array}{c}\text { Research } \\
\text { Proposition } 2\end{array}$ & \\
\hline $\begin{array}{l}\text { Subordinate: } \\
\text { 'Leaders in a Specific Role Interaction' }\end{array}$ & & $\begin{array}{c}\text { Research } \\
\text { Proposition } 3\end{array}$ & & \\
\hline
\end{tabular}

In sum, it is the purpose of the present research to test four research propositions relevant to the conceptual levels of ILTs and gender stereotypes. Table 1 summarizes these research propositions and shows the relationship of each research proposition to the hierarchical conceptualization of ILTs.

\section{METHOD}

\section{Stage I: Card Sort}

Subjects were students in their last two years of education selected from a metropolitan secondary school. The sample consisted of ten student leaders, including two students (i.e., one male and one female) from the following five activity groups: Athletics (e.g., basketball team), club (e.g., yearbook or newspaper), governance (e.g., student body government), performance (e.g., marching band), and work (e.g., part-time off-campus employment). Subjects who met the criteria all volunteered to participate.

The Stage I measure consisted of a stack of 40 index cards with a different leadership statement printed on each card (e. g., "A leader is friendly and approachable," "A leader uses available outside resources," and "A leader encourages teamwork"). Five statements were created for each of eight leadership constructs. Some of the items were taken from the Leader Behavior Description Questionnaire Form XII (Stogdill, 1963) and modified for use here.

The school's principal was contacted to gain permission to conduct research within the school and to name students that met the selection criteria. Each subject was given a sheet containing brief descriptions of the eight leadership constructs and the 40 behavioral statement cards. Subjects sorted the leadership statement cards into piles that they felt corresponded to each leadership construct. Cohen's kappas were calculated to determine subject agreement with the expected classification of the items (i.e., expectations consistent with research using adult participants). This index measures agreement over and above the agreement to be expected if judgments are strictly independent (Hays, 1994). The mean of the eight pairwise kappas was 0.82 . This indicates good item reliability for the constructs (see Table 2 for a list of constructs and associated items). These results support research proposition one about student ILTs at the superordinate level. 
Table 2. Leadership Constructs and Individual Item Assessments

\begin{tabular}{|c|c|}
\hline Leadership Construct & Individual Item \\
\hline \multirow{5}{*}{ Consideration } & Is friendly and approachable. \\
\hline & Is concerned with the welfare of group members. \\
\hline & Listens carefully to group member's ideas and problems. \\
\hline & Puts suggestions made by the group into action. \\
\hline & Treats all group members as his or her equal. \\
\hline \multirow{5}{*}{ Responsibility } & Believes that he or she can get the job done. \\
\hline & Accepts responsibility for his or her actions. \\
\hline & Is willing to take risks. \\
\hline & Has faith in himself or herself. \\
\hline & Trusts his or her own instincts. \\
\hline \multirow{5}{*}{ Motivation } & Tries to bring out the best work of group members. \\
\hline & Keeps the group members focused on their goal. \\
\hline & Maintains high standards. \\
\hline & Keeps the group members working at peak performance. \\
\hline & Encourages the group to continually do better. \\
\hline \multirow{5}{*}{ Initiate Structure } & Lets group members know what is expected of them. \\
\hline & Determines what shall be done and how it shall be done. \\
\hline & Asks group members to follow standard rules. \\
\hline & Develops guidelines or rules for group behavior. \\
\hline & Decides when and where the group will meet. \\
\hline \multirow{5}{*}{ Problem Solving } & Weighs all the options before making a decision. \\
\hline & Comes up with many different solutions to a problem. \\
\hline & Develops strategies to solve problems. \\
\hline & Anticipates and responds quickly to problems. \\
\hline & Removes obstacles that get in the way of doing the job. \\
\hline \multirow{5}{*}{ Network } & Speaks for the group when visitors are present. \\
\hline & Uses available outside resources. \\
\hline & Makes necessary arrangements with those outside the group. \\
\hline & Publicizes the activities of the group. \\
\hline & Talks with others on behalf of the group. \\
\hline \multirow{5}{*}{ Building Teams } & Gets group members to work together. \\
\hline & Encourages teamwork. \\
\hline & Encourages group members to offer and exchange ideas. \\
\hline & Helps group members settle differences. \\
\hline & Keeps the group united. \\
\hline \multirow{5}{*}{ Expertise } & Is among the best at the group's task. \\
\hline & Is very knowledgeable of the task at hand. \\
\hline & Can tell the difference between good and bad work. \\
\hline & Is one of the most gifted and talented of the group members. \\
\hline & Is highly skilled at performing the group's work. \\
\hline
\end{tabular}

\section{Stage II: Questionnaire Study}

A new sample consisting of subjects selected from 14 urban and rural secondary schools as well as surrounding area restaurants was used in Stage II. An adult leader, a student leader, and three student group members were sampled from each school or restaurant for each activity group: athletics (e.g., basketball), clubs (e.g., journalism), governance (e.g., officers in the associated student body), performance (e.g., band), and work (e.g., employees at a restaurant). Adult and student leaders were selected by activity (i.e., they were the leaders of their respective groups). Student activity members were selected by the adult leaders. The only criteria suggested to adult leaders for selecting group members as participants was that the group activity members should have been a member of the group for at least one year and, when possible, they try to select both males and females.

The Stage II measure consisted of a questionnaire listing all 40 leadership statements. Subjects were asked to think about how frequently an ideal leader would engage in the behavior described by the leadership statement. Subjects 
rated each item using a five point Likert-type scale. For example: An ideal student leader treats all group members as his or her equal and this was rated by selecting from Never(1), Seldom(2), Sometimes(3), Often(4), Always(5). Subjects rated the 40 items three times in total, each time considering a different target is an ideal leader. They first considered the ideal student leader in their ratings, then they considered the ideal adult advisor or supervisor as the leader, and finally they considered an ideal leader in general.

Questionnaires were distributed to adult leaders at their schools along with cover letters describing the voluntary and confidential nature of the study. Adults were asked to anonymously complete the questionnaire themselves and distribute copies of the questionnaire and cover letter to three student group members and group's student leader. After subjects completed the questionnaire anonymously, they returned them in a supplied postage-paid envelope.

Of the 350 surveys that were distributed 157 were returned. Four of the returned surveys were unusable (e.g., largely incomplete responses) and excluded from further analysis. Of the 70 surveys distributed to the part-time work group, only eight were returned. Thus the work group was dropped from further analyses due to the low return rate. Of the remaining 280 surveys distributed to the athletics, club, performance, and governance activity groups, 145 were returned in usable condition for a response rate of $52 \%$. Fifty-five males and 76 females returned surveys, and 14 subjects did not indicate their gender. Three students were in the ninth grade (i.e., the first year of secondary education), 22 students were in the second year of secondary school, 31 students were in the third year, and 44 students were in the fourth year. The average age of the student subjects with 16.8 years of age. Six students did not report their year in school or age. The average age of the adult subjects was 41.8 years old. Twelve adult subjects did not report their age (see Table 3 for a list of the subjects by role and activity).

Table 3. Subjects Classified by Role, Sex, and Activity

\begin{tabular}{l|c|c|c|c|cc}
\hline \multirow{2}{*}{ Activity Group } & \multicolumn{2}{|c|}{ Adult Leader } & \multicolumn{2}{c|}{ Student Leader } & \multicolumn{2}{c}{ Student Group Member } \\
\cline { 2 - 7 } & Male & Female & Male & Female & Male & Female \\
\hline Basketball & 9 & 0 & 3 & 5 & 5 & 10 \\
\hline Journalism & 5 & 3 & 2 & 7 & 6 & 18 \\
\hline Government & 3 & 5 & 2 & 2 & 5 & 12 \\
\hline Band & 7 & 0 & 4 & 5 & 20 & 4 \\
\hline Totals & 24 & 8 & 11 & 19 & \\
\hline
\end{tabular}

RESULTS

A reliability analysis was performed on item ratings for each group of five leadership expectation items associated with previously identified constructs. This analysis was performed for each of the three leader target surveys (e.g., adult leaders, leaders in general, and student leaders). Table 4 shows all construct items demonstrated acceptable levels of internal reliability across all targets with the exception of the modest level internal reliability shown for items associated with the responsibility construct for Student at Leader as target $(\alpha=.57)$. These results support research proposition one about ILTs at the superordinate level. 
Table 4. Descriptive Statistics, Reliabilities, and Intercorrelations

\begin{tabular}{|c|c|c|c|c|c|c|c|c|c|c|}
\hline Rating & $\mathbf{M}$ & SD & $\alpha$ & 1 & 2 & 3 & 4 & 5 & 6 & 7 \\
\hline \multicolumn{11}{|c|}{ Student Leaders $(N=143)$} \\
\hline Consideration & 22.3 & 2.15 & .66 & & & & & & & \\
\hline Responsibility & 22.1 & 1.81 & .57 & .45 & & & & & & \\
\hline Motivation & 22.5 & 1.99 & .71 & .50 & .36 & & & & & \\
\hline Initiate Structure & 19.4 & 2.60 & .62 & .18 & .35 & .38 & & & & \\
\hline Problem Solving & 20.7 & 2.36 & .69 & .53 & .35 & .48 & .48 & & & \\
\hline Networking & 19.1 & 2.57 & .64 & .32 & .31 & .18 & .58 & .54 & & \\
\hline Building Teams & 21.7 & 2.37 & .72 & .64 & .42 & .60 & .35 & .60 & .45 & \\
\hline Expertise & 19.7 & 2.73 & .74 & .13 & .44 & .27 & .57 & .37 & .33 & .16 \\
\hline \multicolumn{11}{|c|}{ Adult Leaders ( $N=145)$} \\
\hline Consideration & 22.9 & 2.66 & .71 & & & & & & & \\
\hline Responsibility & 22.6 & 2.00 & .63 & .57 & & & & & & \\
\hline Motivation & 23.2 & 2.36 & .82 & .63 & .60 & & & & & \\
\hline Initiate Structure & 21.3 & 2.86 & .75 & .40 & .56 & .70 & & & & \\
\hline Problem Solving & 21.7 & 2.52 & .75 & .47 & .65 & .57 & .64 & & & \\
\hline Networking & 20.5 & 2.90 & .73 & .38 & .52 & .47 & .65 & .61 & & \\
\hline Building Teams & 22.2 & 2.63 & .75 & .71 & .59 & .67 & .59 & .62 & .55 & \\
\hline Expertise & 20.9 & 3.51 & .86 & .37 & .62 & .39 & .47 & .55 & .48 & .41 \\
\hline \multicolumn{11}{|c|}{ Leaders in General $(\mathrm{N}=143)$} \\
\hline Consideration & 22.3 & 2.49 & .76 & & & & & & & \\
\hline Responsibility & 22.5 & 2.11 & .68 & .59 & & & & & & \\
\hline Motivation & 22.7 & 2.58 & .85 & .67 & .67 & & & & & \\
\hline Initiate Structure & 20.4 & 2.84 & .75 & .35 & .41 & .53 & & & & \\
\hline Problem Solving & 22.6 & 2.67 & .82 & .67 & .60 & .63 & .57 & & & \\
\hline Networking & 19.6 & 2.83 & .73 & .50 & .41 & .47 & .69 & .66 & & \\
\hline Building Teams & 22.0 & 2.59 & .78 & .70 & .57 & .78 & .59 & .70 & .66 & \\
\hline Expertise & 20.8 & 3.09 & .83 & .28 & .37 & .32 & .52 & .44 & .50 & .37 \\
\hline
\end{tabular}

Each subject's ratings for the five leadership statement items associated with a particular construct were summed to create a new variable. Thus, the scores of all five items associated with consideration on the questionnaire were summed to form a variable called Consideration (see Table 2). The next five items in Table 2 formed a variable labeled Responsibility, the next five forms Motivation, the next five items create Initiate Structure, the next five form Problem Solving, the next five constitute Network, the next five form Building Teams, and the last five forms Expertise. All multivariate analyses utilize these aggregate variables as measures of leadership expectations. Three separate 3 (Role: Adult Leader, Student Leader, or Student Group Member) by 4 (Activity: Basketball, Journalism, Student Government, Band) MANOVAs were performed: one using student leader ratings as the dependent variable, one for adult leaders as the dependent variable, and one for leaders in general as the dependent variable. Each MANOVA was performed to determine if subjects' leadership expectations differed depending on their role and/or activity. Three one-way MANOVA's were performed to determine if male and female students differed on their leadership expectations.

\section{Adult Leader as Target}

Results of the 3(Role) x 4(Activity) MANOVA reveal significant effects by activity on expectations for adult leaders (Wilks $\lambda=.56, \mathrm{~F}(24,366)=3.33$, $\mathrm{p}<.001$; see Table 5). Univariate analyses for activity shows that subjects' expectations differ in three areas of adult leader behavior: Responsibility $(\mathrm{F}(3,133)=4.18, \mathrm{p}<.01)$, Motivation $(\mathrm{F}(3,133)=3.51, \mathrm{p}<.05)$, and Initiate Structure $(\mathrm{F}(3,133)=8.67, \mathrm{p}<.001)$. Bonferroni's post-hoc comparison procedure was used to find significant group differences in expectations for adult leaders. Members of Student Government (Mean=21.9) have significantly lower expectations for adult leaders regarding Responsibility than Basketball team members (Mean=23.2) and Band members for Responsibility (Mean=23.3). Journalism group members had lower expectations (Mean=22.1) than Band members in this area. Expectations for adult leaders as motivators or goal setters is significantly lower for Student Government members (Mean=22.4) than for both Basketball team members $($ Mean=23.9) and Band members (Mean=24.0). Student Government (Mean=20.2) and Journalism group members (Mean=20.2) have lower expectations of adult leaders' Initiating Structure within the group than did Band 
(Mean=22.6) or Basketball team members (Mean=22.7). Taken as a whole, these results support research proposition two regarding the basic hierarchical level of ILTs. A MANOVA testing differences by student gender is not significant.

Table 5. Multivariate Analysis of Variance Results for Adult Leader as the Target: 3 (Role) x 4 (Activity)

\begin{tabular}{l|c|c|c|c}
\hline \multicolumn{1}{c|}{ Effect } & Willks' Lambda & F & Significance & df \\
\hline Role $x$ Activity & .69 & 1.02 & $\mathrm{~ns}$ & 48,624 \\
\hline Activity & .56 & 3.33 & $\mathrm{p}<.001$ & 24,366 \\
\hline Role & .84 & 1.46 & $\mathrm{~ns}$ & 16,252 \\
\hline
\end{tabular}

Note: $\mathrm{N}=145$

\section{Leaders in General}

The 3(Role) x 4(Activity) MANOVA shows significant effects by role on expectations for leaders in general (Wilks $\lambda=.80, \mathrm{~F}(16,248)=1.81, \mathrm{p}<.05$; see Table 6 ). A univariate analysis for role shows that subjects differ on expectations for Consideration from leaders in general $(\mathrm{F}(2,131)=4.34, \mathrm{p}<.05)$. Those who are student activity group members expect significantly more consideration from leaders in general (Mean=22.6) than do adults (Mean=21.2); additionally student leaders' ratings (Mean=22.5) were higher than the adults' ratings. With the exception of the Consideration scale, these results support research proposition one concerning superordinate ILTs.

Table 6. Multivariate Analysis of Variance Results for Leaders in General as the Target: 3 (Role) x 4 (Activity)

\begin{tabular}{l|c|c|c|c}
\hline \multicolumn{1}{c|}{ Effect } & Willks' Lambda & F & Significance & df \\
\hline Role x Activity & .73 & 0.86 & $\mathrm{~ns}$ & 48,614 \\
\hline Activity & .78 & 1.37 & $\mathrm{~ns}$ & 24,360 \\
\hline Role & .80 & 1.81 & $\mathrm{p}<.05$ & 16,248 \\
\hline
\end{tabular}

Note: $\mathrm{N}=143$

A MANOVA testing differences by student raters' sex is significant $(\mathrm{F}(8,90)=2.04, \mathrm{p}<.05)$. Female students expect more consideration (Mean=23.2) than do male students $(M e a n=21.5)$. Females also expect more Problem Solving from leaders in general (Mean=22.0) than do males (Mean=20.5). These findings support research proposition four regarding gender differences.

\section{Student Leaders as Targets}

Results of the $3 \times 4$ MANOVA reveal significant effects by activity (Wilks $\lambda=.74, F(24,360)=1.63$, $p<.05$; see Table 7). Differences by role are not significant. The univariate analysis for activity shows that subjects significantly differ on expectations for student leaders on Problem Solving $(F(3,131)=3.42, p<.05)$. Only one significant comparison is found using Bonferroni's post-hoc comparison procedure. Those involved in Journalism expect more problem-solving behavior from student leaders (Mean=21.3) than do those involved in Band (Mean=19.8).

Table 7. Multivariate Analysis of Variance Results for Student Leader as the Target: 3 (Role) x 4 (Activity)

\begin{tabular}{l|c|c|c|c}
\hline \multicolumn{1}{c|}{ Effect } & Willks' Lambda & F & Significance & df \\
\hline Role x Activity & .63 & 1.22 & $\mathrm{~ns}$ & 48,614 \\
\hline Activity & .74 & 1.63 & $\mathrm{p}<.05$ & 24,360 \\
\hline Role & .82 & 1.63 & $\mathrm{~ns}$ & 16,248 \\
\hline
\end{tabular}

Note: $\mathrm{N}=143$

A MANOVA testing differences by student raters' sex is significant Wilks' $\lambda=.84, F(8,90)=2.16, p<.05)$. A univariate analysis for student raters' sex reveals that male and female students differ on expectations of student leader Consideration $(\mathrm{F}(1,97)=10.64, \mathrm{p}<.01)$. In this sample female students expect significantly more Consideration from student leaders (Mean=23.1) than do male students (Mean=21.7). These findings support research proposition four regarding gender differences. 


\section{Differences in Students' Expectations of Targets}

A repeated measures analysis of variance (i.e., a within subjects design) was performed on each leadership construct. The analysis was performed using only student subjects $(\mathrm{n}=106)$. The purpose of this analysis was to determine if students (i.e., pooled across roles and activities) have different leader expectations for different types of leaders. For example, do students expect more, less, or the same amount of consideration from student leaders, adult leaders, and leaders in general (i.e., relevant to research proposition three)?

The repeated measures analysis revealed that student expectations differed depending on the type of leader or target for Motivation $(\mathrm{F}(2,210)=4.02, \mathrm{p}<.05)$, Initiate Structure $(\mathrm{F}(2,210)=14.87, \mathrm{p}<.001)$, Problem Solving $(\mathrm{F}(2,210)=4.57, \mathrm{p}<.05)$, Networking $(\mathrm{F}(2,210)=9.10, \mathrm{p}<.001)$, and Expertise $(\mathrm{F}(2,210)=12.75, \mathrm{p}<.001$; see Table 8). Follow-up analyses using t-tests for paired samples gave the following significant results. Students expect significantly higher levels of leadership from adult leaders than student leaders for Motivation (Adult Leaders Mean=23.2 and Student Leaders Mean=22.6), for Initiate Structure (Adult Leaders Mean=21.2 and Student Leaders Mean=19.6), for Problem Solving (Adult Leaders Mean=21.7 and Student Leaders Mean=21.0), for Networking (Adult Leaders Mean=20.6 and Student Leaders Mean=19.5), and for Expertise (Adult Leaders Mean=20.8 and Student Leaders Mean=19.7). However no significant difference exists between adult leader expectations and expectations for student leaders on Consideration and Responsibility.

Table 8. Repeated Measures Analyses of Students' Construct Ratings of Leadership Three Targets

\begin{tabular}{l|c|c|c}
\hline Leadership Expectation Variable & F & Significance & df \\
\hline Consideration & 2.31 & $\mathrm{~ns}$ & 2.210 \\
\hline Responsibility & 2.81 & $\mathrm{~ns}$ & 2,210 \\
\hline Motivation & 4.02 & $\mathrm{p}<.05$ & 2,210 \\
\hline Initiate Structure & 14.87 & $\mathrm{p}<.001$ & 2,210 \\
\hline Problem Solving & 4.57 & $\mathrm{p}<.05$ & 2,210 \\
\hline Networking & 9.10 & $\mathrm{p}<.001$ & 2,210 \\
\hline Building Teams & 0.80 & $\mathrm{~ns}$ & 2,210 \\
\hline Expertise & 12.75 & $\mathrm{p}<.001$ & 2,210 \\
\hline
\end{tabular}

Note: $\mathrm{N}=106$

These results are paralleled by results showing students expect significantly higher levels of leadership behaviors from leaders in general than student leaders on Initiate Structure, Problem Solving, Networking, and Expertise. In only two cases are there different expectations for adult leaders than from leaders in general; adult leaders are expected to show more Initiate Structure $(M e a n=21.2)$ than leaders in general (Mean=20.4) and adult leaders were expected to show more Networking (Mean=20.6) than leaders in general $(M e a n=20.0)$. Taken together the repeated measures analyses support research proposition three regarding the subordinate hierarchical level for ILTs

\section{DISCUSSION}

By collecting behavioral measures related to expectations for leadership, this research has provided empirical evidence that supports the conclusion that secondary school students as young as 16 years of age have mental models for leadership behavior or implicit leadership theories that are very similar to those held by working adults. Participants reliably sorted behavioral statements into groups reflecting commonly reported leadership constructs. In a second sample, student participants used ratings forms to report expectations for ideal leadership behaviors for three distinct types of leaders: Student leaders, adult leaders, and leaders in general. This supports the conclusion that these mental models form in adolescence without formal coursework on leadership or without experiencing fulltime employment. As teenagers experience new groups and opportunities for leadership experience, it seems reasonable to conclude that social exchange concepts applicable to leadership emergence (c.f., Hollander, 1984) operate. Data presented here support the conclusion that superordinate level ILTs are used by secondary school students before entering full-time employment. As Foti and Luch (1992) argued, leaders compare their own behavior with self-generated behavioral standards derived from leadership prototypes. Schyns, Kiefer, Kerschrieter, and Tymon (2011) noted that implicit leadership theories impact students' self-concepts and their own leadership identity. It is this leadership identity that may determine how successful individuals are in leadership emergence opportunity situations. 
These results provide strong support for Calder's (1977) attributional model for leadership and its emphasis on the use of social context to add meaning to the interpretation of leadership actions. The student raters in this study clearly perceived needs for different types of leadership given the goals of their activity group. Type of extracurricular activity has a major influence on students' expectations for adult leaders and these differences in expectations appear in the areas of accepting responsibility and acting confident, motivating the group and keeping them focused, and structuring group procedures and activities. Those involved in music performance and those in athletics teams expect more from their adult leaders in each of these three areas than do those involved in student government or in journalism groups. These results support the conclusion that basic level ILTs held by secondary school students reflect the values or goals of the group they identify with and participate in (c.f., Lord, Foti, \& De Vader, 1984).

Why do students involved in performance or athletics groups expect more behavior reflecting initiating structure, responsibility, and motivation from their adult leaders? One possible explanation lies in the similar characteristics of their activities. Music performance group and athletics team practices are organized in similar ways. For both activities, a practice session typically contains a warm-up, a drill, focused practice, and simulations. It should be clear that both of these activities are highly structured and the structure initiated by the music director or athletics coach. Students in these groups and student leaders of these groups have little input in the customary structure of their activities.

This is in contrast to journalism and student government groups and their leaders, who are given much more freedom to guide the structure of their meetings in their day-to-day activities. The adult leaders often act more as an advisor or mentor than a director. This could account for higher expectations for initiating structure from music directors or from athletics coaches over the adult leaders of other groups. Research Proposition Three held that the role of leader to the perceiver would affect the ILTs held by students. The repeated measures analyses reported here show the students clearly differentiated their expectations based on the target leader to be described. The support for the first three research propositions taken together demonstrates the heuristic power of the hierarchical model of implicit leadership theories (Lord, Foti, \& Phillips, 1982; Lord, Foti, \& De Vader, 1984). Results from this study relate to Keller's (1999) data showing correlations between parental traits and university students' ILTs, thus supporting the conclusion that parents, teachers, and coaches as authority figures shape expectations for future interactions with authorities.

Nichols and Erakovich (2013) noted that feedback on leadership effectiveness may affect ILTs based on inferences but that recognition-based perceptual processes (i.e., the fit between observed leader behavior and the ILT held by the observer) may be more stable over time. This study focused on leadership expectations and did not focus on observed leadership acts, thus it follows the reasoning of Nichols and Erakovich (2013) that the antecedents of the ideal may influence the ILT before personal experience as a leader or acquiring extensive leadership skills. 'Leadership categorization theory is more than explanation of leadership perceptions; it is also an explanation of how knowledge structures related to leadership are organized in memory and how people are likely to process information related to leadership' (Foti \& Luch, 1992; p. 56).

What do these findings imply for leadership development? Student leaders who are involved in performance or athletics groups may not have the same opportunities to develop organizational skills through experience in initiating structure. For these young leaders, special emphasis should be placed on increasing proficiency in developing, planning, and organizing group activities. For example, coaches and band directors could delegate to student leaders the creation of a practice scheme or rehearsal schedule one day a week or they might be asked to help develop guidelines for other group members' activities.

One aspect of music groups and athletics teams that may help explain why students expect more motivational behaviors from their adult leaders is that they are both oriented towards competition and performance. Bands are especially competitive in the high school level since marching, symphonic, and jazz band contests are held year round. Obviously, adult leaders must be adept and innovative to motivate their group members to practice hard on a daily basis. They must keep the group focused and get them energized before any competition. Student government on the other hand is oriented toward service. While some motivation assistance is required from student government adult leaders, it would seem unlikely that it matches the level of necessity or intensity of coaches and band directors. 
Some of the more intriguing results from this study arise from comparing student leaders' ratings to student group members' ratings. It does not appear that in terms of forming expectations for ideal leadership that experience in student leadership roles adds anything to the mental models held by adolescents. While there may be value in an individual holding student leadership roles with regard to skill development, in terms of the understanding of leadership and its functions these results do not support that conclusion when student leaders and group members are compared directly (see Table 7). In a sense then, contingency approaches to understanding leadership (Yukl, 2010) may be formed best by allowing students exposure to a variety of secondary school experiences rather than guiding students to longer term experience in a single type of student group or emphasizing attaining a leadership position.

The debate over gender effects in leadership style has a long history but the empirical evidence for different expectations for experienced leadership is not as well established (Eagly \& Johnson, 1990). In this study no data was collected on students' enacted leadership styles but instead expectations for idealized leadership functions were evaluated. Results support the conclusion that females in secondary school expect more consideration behaviors from student leaders and from leaders in general than do males. Socialization into gender specific expectations appears to occur outside formal training or employment. These idealized expectations may be a well spring for later differences in practiced leadership styles.

The sex-role stereotype of women as leaders includes the expectation that female leaders will be more considerate than male leaders in their demonstrated actions (Petty \& Lee, 1975). In general, the stereotype is held by both women and men. While the validity of this stereotype is supported by laboratory experimentation in assessment studies, it is not supported in organizational studies. Eagly and Steffen $(1984,1986)$ showed that women's employment stereotypes are more agentic (e.g., competitive, individualistic) and less communal (e.g., kind, nurturing) than those identified with domestic roles. See Eagly and Johnson (1990) for a meta-analysis of this literature. In the present study, however, there is no gender attached to the idealized target leaders. Diekman and Eagly (2000) used social role theory to argue that gender stereotypes emerge from role-bound activities over time and they presented evidence that the female stereotype is particularly dynamic.

Why would females expect more consideration from student leaders and leaders in general, and not from adult leaders? A possible answer to this question is offered in two parts. First, cognitive prototypes are developed through experience. Occupations are sex-typed when the majority of those in a particular occupation are members of one sex (Schein, 1973). For example, the normative expectations of a commercial airline pilot include an expectation that the pilot is male. In the present study 32 of the 39 adult leader subjects reported their sex and of those 32, 24 or $75 \%$ were males (See Table 3). All basketball coaches and band directors were male. A slight majority of journalism instructors were male. Only in student government were there slightly more female adult leaders than male adult leaders. Therefore, it seems likely that the prototype of the adult leader is that of a male for the majority of subjects.

However, in the case of student leaders, the number of female and male leaders was even in student government, slightly greater for females in band and basketball, and much greater for females in journalism. Note that theoretically the number of female and male student leader should be equal in the case basketball teams since the teams are composed entirely of either male or female players. The point here is that with a greater balance in student leader gender, student leader prototypes are less likely to be sex-stereotyped. In the case of leaders in general, it is difficult to say whether subjects attached a specific gender to this target. The nature of this target leader is ambiguous given the nature of rating leaders in general.

The second part of the explanation for why females expect more consideration involves a hypothesized link between the sex of the subject and gender associated with the idealized leader. If both male subjects' and female subjects' prototypes of adult leaders includes a male sex-stereotype, then we would see no difference in their expectations for consideration. Indeed, in this study, no difference was found. However, in the case of student leaders and leaders in general, where sex typing of the target leader does not exist, we would see a difference in consideration expectations if female subjects' prototypes were more often female and male subjects' prototypes were more often male. In other words, in their contemplation of idealized student leaders and leaders in general, if females think of females and males think of males, this would account for differences in expectations of consideration. This hypothesis, that an individual's prototype of a non-sex stereotyped occupation (e.g., a teacher) or position (e.g., leader) is related to the sex of the individual holding the prototype, is worthy of further investigation. 
What are the implications for leadership education of this finding that females expect more consideration from their student leaders than males? It is difficult to say until the underlying cause for such expectations is found. Ayman and Korabik (2010) have said that the lack of attention to such factors as gender in the study of leadership creates problems for improving existing leadership development procedures. The leaders of tomorrow need to understand their own preferences, as well as those of others, to learn how to be recognized as a group leader.

'One the one hand, female leaders are expected to take charge and approach leadership in the same ways as their male colleagues. On the other hand, female leaders are expected to deliver the warmth and friendliness that is culturally prescribed for women. Simultaneously impressing others as a good leader and a good woman is an accomplishment that is not necessarily easy to achieve (Eagly \& Chin, 2010; p.218).'

This study has dealt with expectations for idealized leadership and no data on observed or practiced leadership behaviors were collected. The study did not formally analyze students exposed to classroom instruction on leadership or even explicit training on leadership and there was no control for students' prior exposure to leadership concepts or leadership theories. Additionally, results reported here likely are affected by common method variance, as are all questionnaire studies without other data sources. Finally, student activity groups reflect not just differences in extra-curricular interests but they may also attract different types of individuals. Characteristic differences between students attracted to club activities versus performance groups, for example, could not be assessed in this study.

Future research on the development of ILTs should collect data on the practiced or implemented behaviors of student leaders. This could be done in a type of multi-rater/multi-attribute matrix such that students in leadership roles are rated on a number of behaviors (such as those studied here) by collecting self-ratings, ratings from observations of the group leader by members, and by third party raters. Just as Epitropaki and Martin (2005) stressed the need for studies of longer duration leader-follower relationships, such data would be further enhanced by controlling for prior exposure to leadership models or theories of leadership. Alternatively, a pre- and post-test design of students entering into and exiting from a leadership development program (or leadership class) would add to our knowledge of cognitive formation of implicit theories. A third path for future research might focus on gender differences in ideal or practiced leadership behaviors by comparing secondary school samples with university student samples, and then both student samples to working adult samples. Direct comparisons of effect sizes between samples might be studied in this way.

It is reasonable to conclude that implicit leadership theories develop before employment. They are sensitive to early experiences in task performing groups but are not developed solely through experience in leadership roles. Rather, membership in task performing groups and exposure to adult and same-age role models form the basis of socialization into leadership expectations. Sex differences develop early in the formation of mental models and are in place before exposure to socialization in to employment roles or experiencing supervision in work organizations.

\section{AUTHOR BIOGRAPHY}

Dean E. Frost is a professor of business administration at Bemidji State University. He received his Ph.D. from the University of Washington. His research examines leadership, management development, perceptions of social power, and emotional intelligence. Email: dfrost@bemidjistate.edu

\section{REFERENCES}

Antonakis, J., \& Dalgas, O. (2009). Predicting elections: Child's play. Science, 323, 1183.

Ayman, R., \& Korabik, K. (2010). Leadership: Why gender and culture matter. American Psychologist, 65(3), $157-170$.

Ayman-Nolley, S., \& Ayman, R. (2005). Children's implicit theories of leadership. In B. Schyns and J. R. Meindl (Eds.), The Leadership Horizon Series: Implicit Leadership Theories-Essays and Explorations (pp. 227-274). Greenwich, CT: Information Age.

Bass, B. M. (2008). The Bass \& Stogdill Handbook of Leadership: Theory, Research, and Managerial Applications (4 ${ }^{\text {th }}$ ed.). New York: The Free Press.

Baumgardner, T. L., Lord, R. G., \& Foti, J. C. (1990). A prescription for aspiring leaders: Implications of expert-novice schema 
differences and alternative leadership categorization models. Manuscript cited by Foti and Luch (1992) as submitted for publication.

Betts, S. C., Morgan, W., \& Castiglia, B. (2008). Who's a leader? Students' implicit theories of leadership. Allied Academies International Conference: Proceedings of the Academy of Organizational Culture, Communication, and Conflict, 13, 18. Calder, B. (1977). The attribution theory of leadership. In, B. M. Staw \& G. R. Salnacik (Eds.), New Directions in Organizational Behavior (pp. 179-204). Chicago, IL: St. Clair Press.

Den Hartog, D. N., House, R. J., Hanges, P. J., Ruiz-Quintanilla, S. A., and Dorfman, P. W. (1999). Culture specific and crossculturally generalizable implicit leadership theories: Are attributes of charismatic/transformational leadership universally endorsed? Leadership Quarterly, 10(2), 219-256.

Diekman, A. B., \& Eagly, A. H. (2000). Stereotypes as dynamic constructs: Women and men of the past, present, and future. Personality and Social Psychology Bulletin, 26(10), 1171-1188.

Eagly, A. H., and Chin, J. L. (2010). Diversity and leadership in a changing world. American Psychologist, 65(3), $216-224$.

Eagly, A. H., \& Johnson, B. T. (1990). Gender and leadership style: A meta-analysis. Psychological Bulletin, 108, $233-256$.

Eagly, A. H., \& Steffen, V. J. (1984). Gender stereotypes stem from the distribution of women and men into social roles. Journal of Personality and Social Psychology, 46, 735-754.

Eagly, A. H., \& Steffen, V. J. (1986). Gender stereotypes, occupational roles, and beliefs about part-time employees. Psychology of Women Quarterly, 10, 252-262.

Eden, D., \& Leviathan, U. (1975). Implicit leadership theory as a determinant of the factor structure underlying supervisory behavior rating scales. Journal of Applied Psychology, 60(6), 736-741.

Engle, E. M., \& Lord, R. G. (1997). Implicit theories, self-schemas, and leader-member exchange. Academy of Management Journal, 40, 988-1010.

Epitropaki, O., \& Martin, R. (2004). Implicit leadership theories in applied settings: Factor structure, generalizability, and stability over time. Journal of Applied Psychology, 89, 293-310.

Findorff, J. (1991). Providing student with leadership training programs. NASSP Bulletin, 75, 87-89.

Foti, R. J., \& Luch, C. H. (1992). The influence of individual differences on the perception and categorization of leaders. Leadership Quarterly, 3(1), 55-66.

Hays, W. L. (1994). Statistics (5 ${ }^{\text {th }}$ ed.). Independence, KY: Cengage/Wadsworth.

Hogg, M. A., \& van Knippenberg, D. (2003). Social identity and leadership processes in groups.

In M. P. Zanna (Ed.), Advances in experimental social psychology (volume 35, pp. 1-52). San Diego, CA: Academic Press. Hollander, E. P. (1984). Leadership Dynamics: A Practical Guide to Effective Relationships. New York: The Free Press.

Keller, T. (1999). Images of the familiar: Individual differences and implicit leadership theory. Leadership Quarterly, 10(4), 589-607.

Kenney, R. A., Schwartz-Kenney, B. M., \& Blascovich, J. (1996). Implicit leadership theories: Defining leaders described as worthy of influence. Personality and Social Psychology Bulletin, 22, 1128-1143.

Lord, R. G., De Vader, C. L., \& Alliger, G. M. (1986). A meta-analysis of the relation between personality traits and leadership perceptions: An application of validity generalization procedures. Journal of Applied Psychology, 71(3), 402-410.

Lord, R. G., Foti, R. J., \& De Vader, C. (1984). A test of leadership categorization theory: Internal structure, information processing, and leadership perceptions. Organizational Behavior and Human Performance, 34, 343-378.

Lord, R. G., Foti, R. J., \& Phillips, J. S. (1982). A theory of leadership categorization. In J. G. Hunt, U. Sekaran, \& C. A. Schriesheim (Eds.), Leadership: Beyond establishment views (pp. 104-121). Carbondale, IL: Southern Illinois University Press.

Lord, R. G., \& Hall, R. J. (2005). Identity, deep structure and the development of leadership skill. The Leadership Quarterly, 16, 591-615.

Lord, R. G., \& Maher, K. J. (1991). Leadership and information processing: Linking perceptionsand performance. Cambridge, MA: Unwin Hyman.

Nichols, T. W., \& Erakovich, R. (2013). Authentic leadership and implicit theory: A normative form of leadership? Leadership \& Organization Development Journal, 34(2), 182-195.

Nye, J. L., \& Forsyth, D. R. (1991). The effects of prototype-based biases on leadership appraisals: A test of leadership categorization theory. Small Group Research, 22, 360-379.

Park, B. (1986). A method for studying the development of impressions of real people. Journal of Personality and Social Psychology, 51, 907-917.

Petty, M. M., \& Lee, G. K. (1975). Moderating effects of sex of supervisor and subordinate on relationships between supervisory behavior and subordinate satisfaction. Journal of Applied Psychology, 60, 624-628.

Pfeffer, J. (1977). The ambiguity of leadership. Academy of Management Review, 2, 104-112.

Pierro, A., Cicero, L., Bonaiuto, M., van Knippenberg, D., \& Kruglanski, A. W. (2005). Leader group prototypicality and leadership effectiveness: The moderating role of need for cognitive closure. Leadership Quarterly, 16, 503-516.

Ritter, B. A., \& Lord, R. G. (2007). The impact of previous leaders on the evaluation of new leaders: An alternative to prototype matching. Journal of Applied Psychology, 92, 1683-1695.

Rush, M. C., Thomas, J. C., \& Lord, R. G. (1977). Implicit leadership theory: A potential threat to the internal validity of leader 
behavior questionnaires. Organizational Behavior and Human Performance, 20, 93-110.

Schein, V. E. (1973). The relationship between sex role stereotypes and requisite management characteristics. Journal of Applied Psychology, 57, 95-100.

Schyns, B., Kiefer, T., Kerschreiter, R., \& Tymon, A. (2011). Teaching implicit leadership theories to develop leaders and leadership: How and why it can make a difference. Academy of Management Learning \& Education, 10(3), 397-408.

Shaw, J. B. (1990). A cognitive categorization model for the study of intercultural management. Academy of Management Review, 10(3), 435-454

Shondrick, S. J., Dinh, J. E., \& Lord, R. G. (2010). Developments in implicit leadership theory and cognitive science: Applications to improving measurement and understanding alternatives to hierarchical leadership. The Leadership Quarterly, 21, 959-978.

Stogdill, R. M. (1963). Manual for the Leader Behavior Description Questionnaire: Form XII. Columbus, OH: Ohio State University, Bureau of Business Research.

Thatch, S. C., Morgan, W., \& Testaglia, B. (2008). Who's a leader? Students' implicit theories of leadership. Proceedings of the Academy of Organizational Culture, Communications and Conflict, 13-21.

U.S. Department of Labor - The Secretary's Commission on Achieving Necessary Skills (1991). What Work Requires of Schools. Washington, DC: U.S. Government Printing Office.

van Knippenberg, B., \& van Knippenberg, D. (2005). Leader self-sacrifice and leadership effectiveness: The moderating role of leader prototypicality. Journal of Applied Psychology, 90(1), 25-37.

Yukl, G. A. (2010). Leadership in Organizations ( $8^{\text {th }}$ ed.). Englewood Cliffs, NJ: Prentice-Hall. 


\section{NOTES}

